\title{
Values of neo-protestant choral works in Romania
}

\author{
CARMEN ALMĂŞANU \\ "George Enescu” National University of Arts Iasi \\ ROMANIA*
}

\begin{abstract}
Borne from the relevant and efficient expression in the context of contemporary culture, neo-protestant choral spirituality uses a diversified and meaningful language. From the very beginning of the existence of neo-protestant cults on the territory of our country, the establishment of a liturgical repertoire intended for common intonation or by various choral or vocal-instrumental bands has been one of the primordial preoccupations. Along with choral creations translated from the universal literature, there is a significant number of original works created by Romanian composers within the religious services. Due to extremely diverse themes and extrovert character, neo-protestant choral music includes different styles specific to the great tradition of classical, romantic or modern music as well as influences from the extra-European sphere. The text of these creations, which has biblical inspiration or created by the composer, is a means of great diversification in the reproduction of the sound material. Composers and arrangers with high quality music training and a profound understanding of biblical truths, through sound art wanted to contribute to the enrichment of contemporary neo-protestant choral music repertoire, leaving posterity a significant amount of valuable choral pages as inheritance.
\end{abstract}

Keywords: choral music, contemporary neo-protestant composers.

\section{Introduction}

As a continuation of the religious reforms that prompted the protest against the Western Church, starting with the second half of the 19th century, through foreign missionaries, some confessional movements have emerged in Romania, which have been called Neo-protestant cults. The cult of the Baptist Christian Church, the cult of the Christian Church after the Gospel, the cult of the Pentecostal Christian Church and the Seventh-day Adventist Church cult were part of the Neo-protestant cults.

The liturgical music of these cults was originally made up of the Anglo-American and German songs brought by the missionaries. In the religious service, the translation of these songs and their intonation by the entire community of believers first in unison, then by choirs to two or four voices, was the main form of musical manifestation until the period between the two world wars and that of the communist regime, when we witness an

\footnotetext{
*carmen_almasanu@yahoo.com
} 
opening towards the native music, the first generation of composers representing the Classics of the Romanian neo-protestant choral music, who created a music similar to that of the great Romanian composers of choral music in the second half of the nineteenth century. The most important poets of this period were Costache Ioanid and Traian Dorz, while the most representative musical creations were accomplished by the composers Nicolae Moldoveanu, Daniel Stăuceanu, Jean Staneschi, Iovan Miclea, Mircea Ciugudean, Valeriu Burciu, Horst Gehann, Mircea Valeriu Diaconescu, Teodor Caciora.

After the 1989 revolution, highly trained composers and arrangers gave a new impetus to the choral creation, adopting a modern and flexible liturgical expression, contributing to the creation of a significant amount of valuable coral pages.

\section{Contemporary neo-protestant choral creations}

One of the major concerns among neo-protestant churches over time has been the defining of the songs repertoire both for the joint singing of the congregations as well as for the various choral or instrumental bands. Within the religious services of the neo-protestant churches in Romania, during the contemporary period there are both choral works with foreign songs, whose texts have been translated into Romanian, as well as original choral arrangements and works, composed in Romanian by Romanian composers belonging to neo-protestant cults such as: Teodor Caciora, Kenneth Tukker, Iulian Teodorescu, Dor Niculescu, Emanuel Bălăceanu, Răzvan Nemeş, Lari Muntean, Silviu Bratu, Onişor Rodila, Marian Fedur, Andrei Dunca, Mircea

The neo-protestant choral music is an optimistic, bright, cheerful, tonic, exuberant music, capable of mobilizing the believers' souls, who fully participate in the singing within the divine services, a music that responds to their different spiritual needs, amplifying the evangelical message and helping to its anchorage into the affective memory.

The neo-protestant choral music contains a very significant quantity of songs that are chosen according to the liturgical needs or according to their musical value. One of the most important features of liturgical music, that has influenced neo-protestant music throughout its existence, is the primordialness of the word over the melody. The text of the choral works, inspired from the Holy Scripture or created by the composer, due to its extremely varied and rich themes, is a means of nuance and infinite diversification in finding specific modal, harmonic or polyphonic solutions for each song. From this perspective, neo-protestant choral music encompasses different styles of classic, romantic or modern musical tradition as well as influences from the extra-European sphere (pop, rock, gospel, jazz). 
From the structural point of view, the most common in the choral creations present in the liturgical repertoires are the simple forms, the stanzaic ones with chorus (found in coral, hymn, lied), because of their accessibility (given that the choral groups in the non-protestant churches are mostly made up of amateurs), and relatively limited space in cult services. Extensive musical genres such as motet, cantata, oratorio are found in the repertoire of extraliturgical sacred music, intoned in the concert halls by some professional neo-protestant choral or vocal-instrumental bands.

From the point of view of the organization of the musical discourse, the neo-protestant choral music contains both characteristic features of the singing in the primary church (rendered by speech and anaphonic singing), as well as the elements of the Byzantine or modal music such as the ison, the ostinato, the sequences, the movable steps, the chromatic elements, alternative measures, polymethry and polyritmia. Some works are monodic, some harmonic or polyphonic handled, or we can capture all three ways of writing in the same work. Among the polyphonic creation processes used, we find the severe and the free imitation (canon, stretto, fugato). We also mention the possibilities of enlarging the morphological framework by applying the double counterpoint, the use of modulation and transposition, the partitioning of parties. We find a variety of tempi and timbre colors, some of which come from the combination of human and instrumental voice. Harmonically, surprising are the passages in which chromatic elements, the four sound, with seventh, with ninth, with added sounds chord, the placement of the melody in the acute register, elements that contribute to amplifying and enhancing of ideas or feelings transmitted by the text.

In the successive paragraphs we shall stop on some recent works, representative for the neo-protestant liturgical repertoire, signed by the composers Teodor Caciora, Iulian Teodorescu, Kenneth Tukker and Emanuel Bălăceanu.

\subsection{Numai harul ${ }^{1}$ [Only the gift] - Teodor Caciora}

Taking over the well-known melody Numai harul/ Only the gift, created by the composer Nicolae Moldoveanu, on the lyrics of the poet Costache Ioanid, Teodor Caciora creates a remarkable coral arrangement in which the melody and the text, in a perfect interflow, describe in a dazed atmosphere of the Romanian folk song, that gift offered by God to the faithful man.

The form of the piece is bipartite, $\mathbf{A}(\mathbf{a}+\mathbf{a v}) \mathbf{B}(\mathbf{b}+\mathbf{b v})$, in its composition identifying 5 stanzas and one chorus, intoned by the mixed chorus alternating

\footnotetext{
${ }^{1}$ Piece no. 7 from Caciora, T. (2011). Concepte componistice şi interpretataive moderne. $O$ viziune asupra propriei creaţii şi activităti interpretative [Modern composing and interpreting concepts. A vision of their own creation and interpretative activities]. Iasi: Editura Artes.
} 
with the accompanying soloist, according to the following scheme:

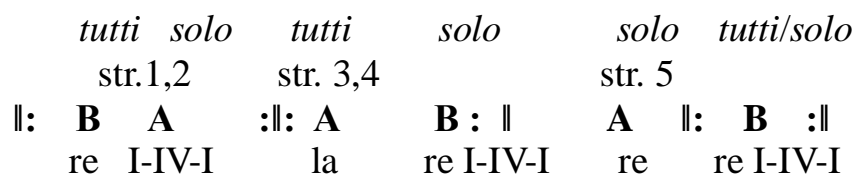

Stanza A, made up of two simple square phrases (a, av), brings a simple melody, embossed with embroidery, passages and appoggiatura, intoned by solo baritone on the long chords of the choir, following the I-IV-I concatenation model.

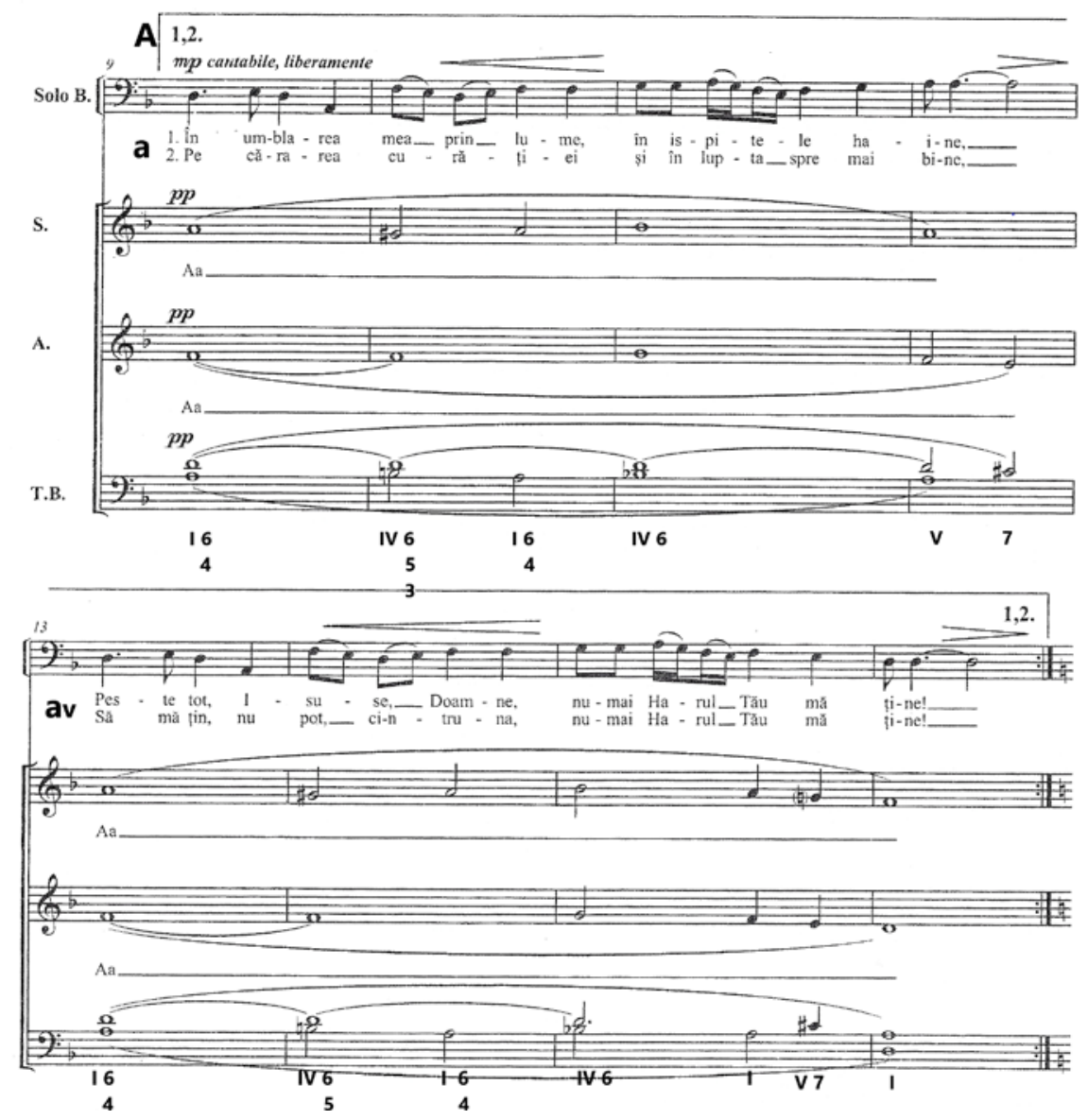

Fig. 1 Teodor Caciora, Numai harul [Only the gift], mm. 9-16

The sound clime of the work is reflected in the oscillations of Dorian mode on the re and la, describing human impotence, that soul-struggle between fall and exaltation. 
s.

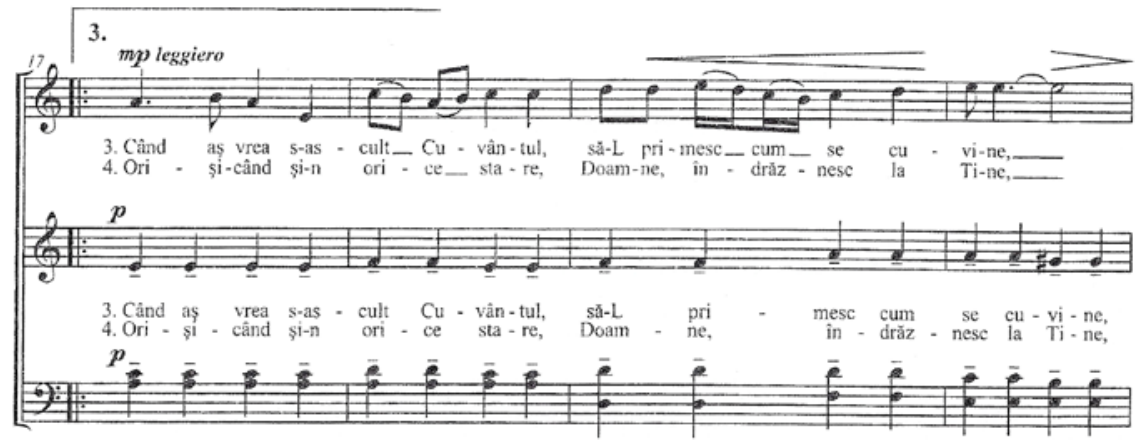

Fig. 2 Teodor Caciora, Numai harul [Only the gift], mm. 17-20

The descant of $\mathbf{B}$ chorus, made up of two simple square phrases in which the composer uses a series of sequences according to the VI-II 7 model, contains the central message of the piece: Numai harul, numai harul mă păstrează nencetat/ El mă face, el mă ține credincios cu-adevărat./ Only grace, only grace keeps me unceasing/ He creates me, he keeps me trully faithful.
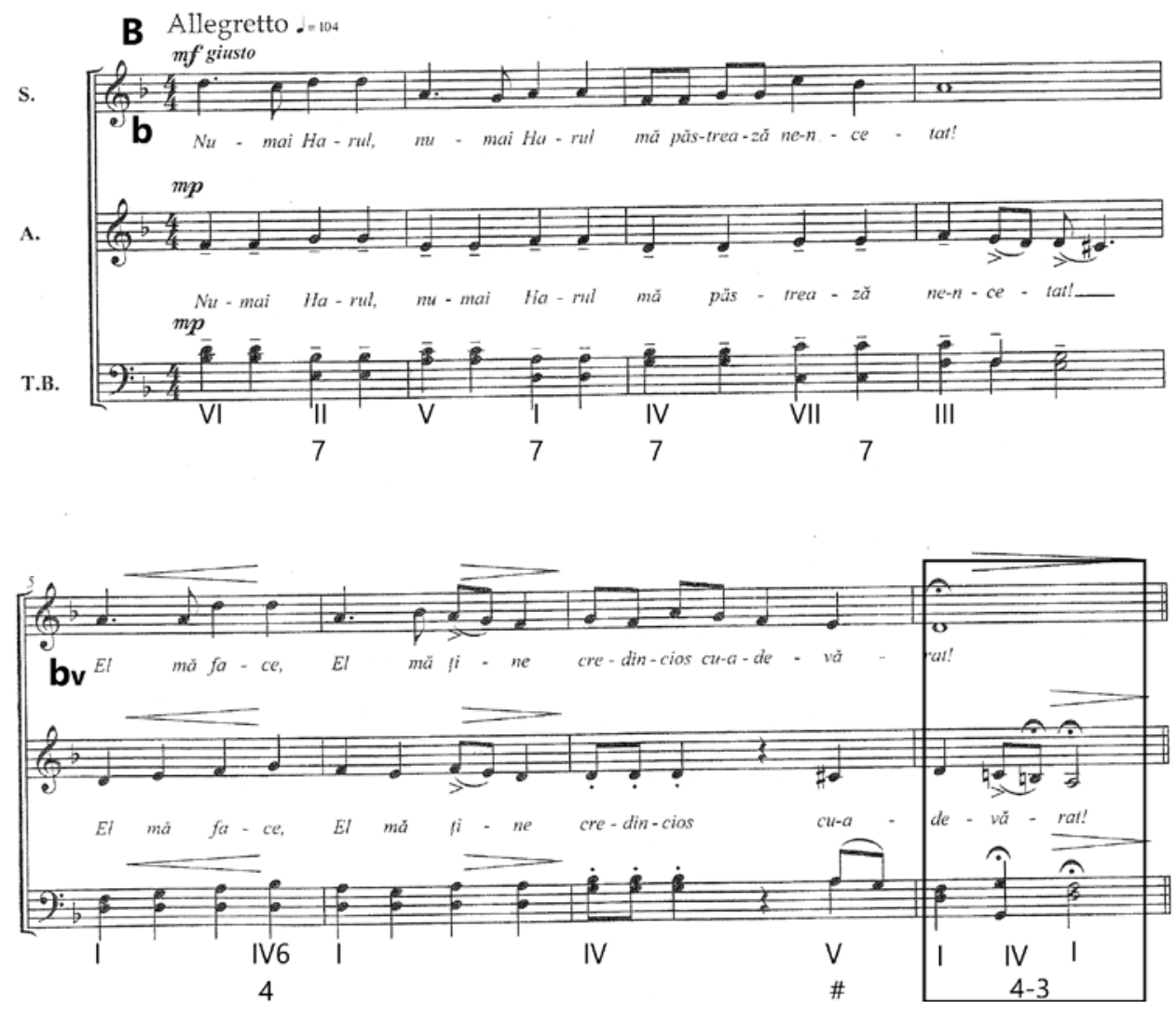

Fig. 3 Teodor Caciora, Numai harul [Only the gift], mm. 1-8 
The last refrain, after the fifth stanza, renders the song intoned by the soloist and the choire together, a process used by the composer to emphasize the importance of the text, the final cadence being achieved through the I-IV major-I chord relation, which is actually a Doric cadence.

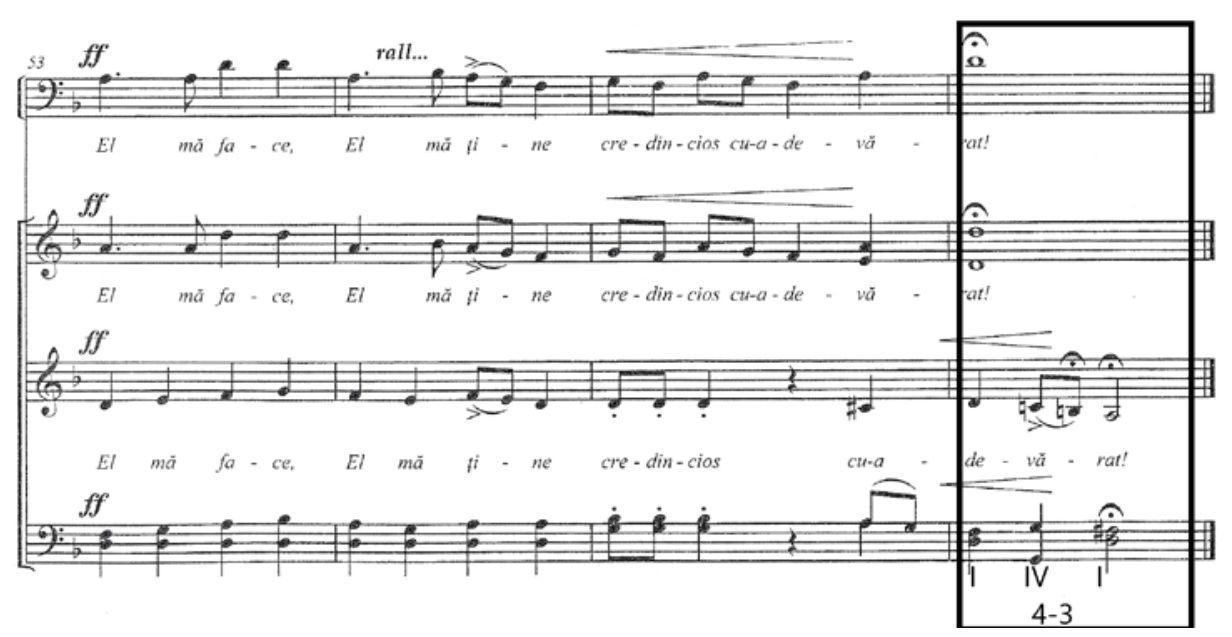

Fig. 4 Teodor Caciora, Numai harul [Only the gift], mm. 53-56

\subsection{Gata îmi este inima să cânte ${ }^{2}$ [Ready is my heart to sing]-Kenneth Tukker}

One of the highly appreciated choral pieces from the repertoire of contemporary neo-protestant music, Gata îmi este inima să cânte-Ready is my heart to sing, belongs to the American composer Kenneth Tukker, who has established itself in Romania for over two decades and has made a remarkable contribution to the revival of choral music. Designed for 4 mixed voices and organ accompaniment, with text taken entirely from Psalm 108 (verses 1, 3, 4 and 5), the piece generates a solemn atmosphere in which feelings of gratitude for the goodness of God that rises above the heavens are expressed.

The text of verse 1, Gata imi este inima să cânte, Dumnezeule./ Ready is my heart to sing, Lord. Voi cânta, voi suna din instrumentele mele, aceasta este slava mea/ I shall sing, play my instruments, this is my lustre, has an introductive function, being intoned in unison by the vocal ensemble, on a simple melody, made up in rising gradual course, combining the binary and triple metre.

2 Piece no. 9 din Un ospăţ nesfârşit [A neverending feast], Collection of choral pieces for mixed choir ( 2012). Oradea: Editura Jubilate. 


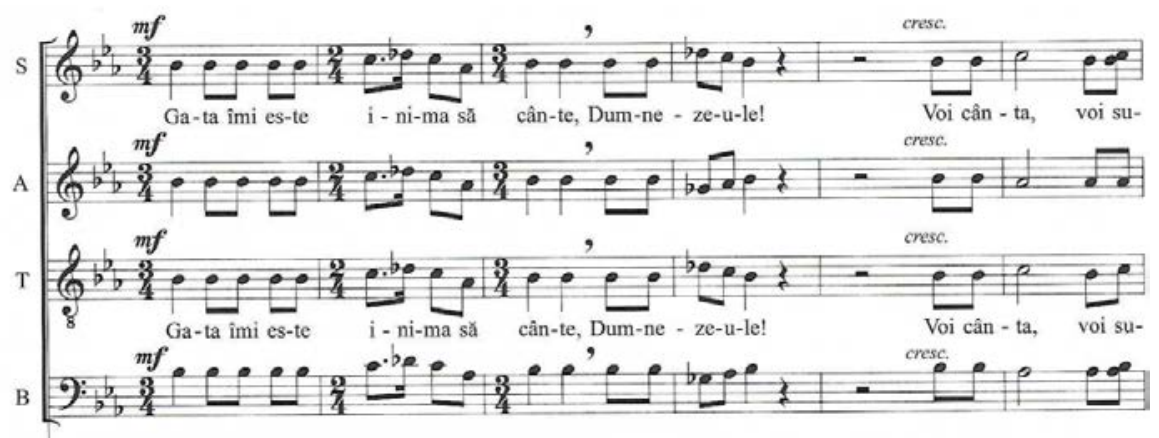

Fig. 5 Kenneth Tukker, Gata îmi este inima să cânte [Ready is my heart to sing], mm. 1-6

The text of the verse 3, Te voi lăuda printre popoare, Doamne,/I shall praise you amongst nations, Lord/ Te voi cânta printre neamuri/I shall seek you amongst nations, brings a new melody, exposed in unison both by the tenor and the bass, taken over by a sopran-alto and continuing with a dialogue between the two vocal groups.

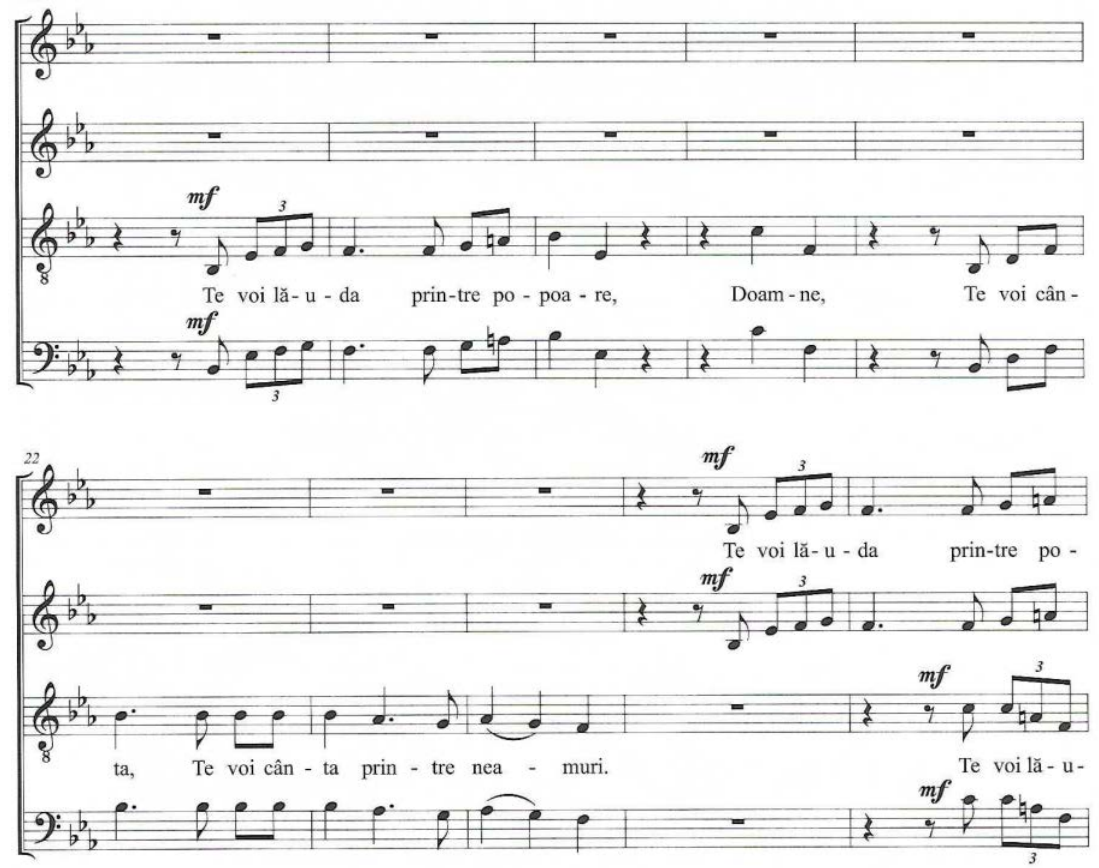

Fig. 6 Kenneth Tukker, Gata îmi este inima să cânte [Ready is my heart to sing], mm. 17-26

Verse 4, Căci mare este bunătatea Ta şi se înalţă mai pe sus de ceruri, iar credincioşia Ta până la nori/ For great is thy lovingkindness, and rises above the heavens, and thy faithfulness unto the clouds, presents us with a page of rare beauty, which reveals the maturity of the compositional thinking and the 
skill of an experienced composer. After the presentation of a new song exposed in unison by the four voices, we see an indedited fragment, made in double counterpoint, by overlapping, then reversing two sound planes with different texts, one of which is the melody of verse 3 , intoned by the bas (mm. 41-51).
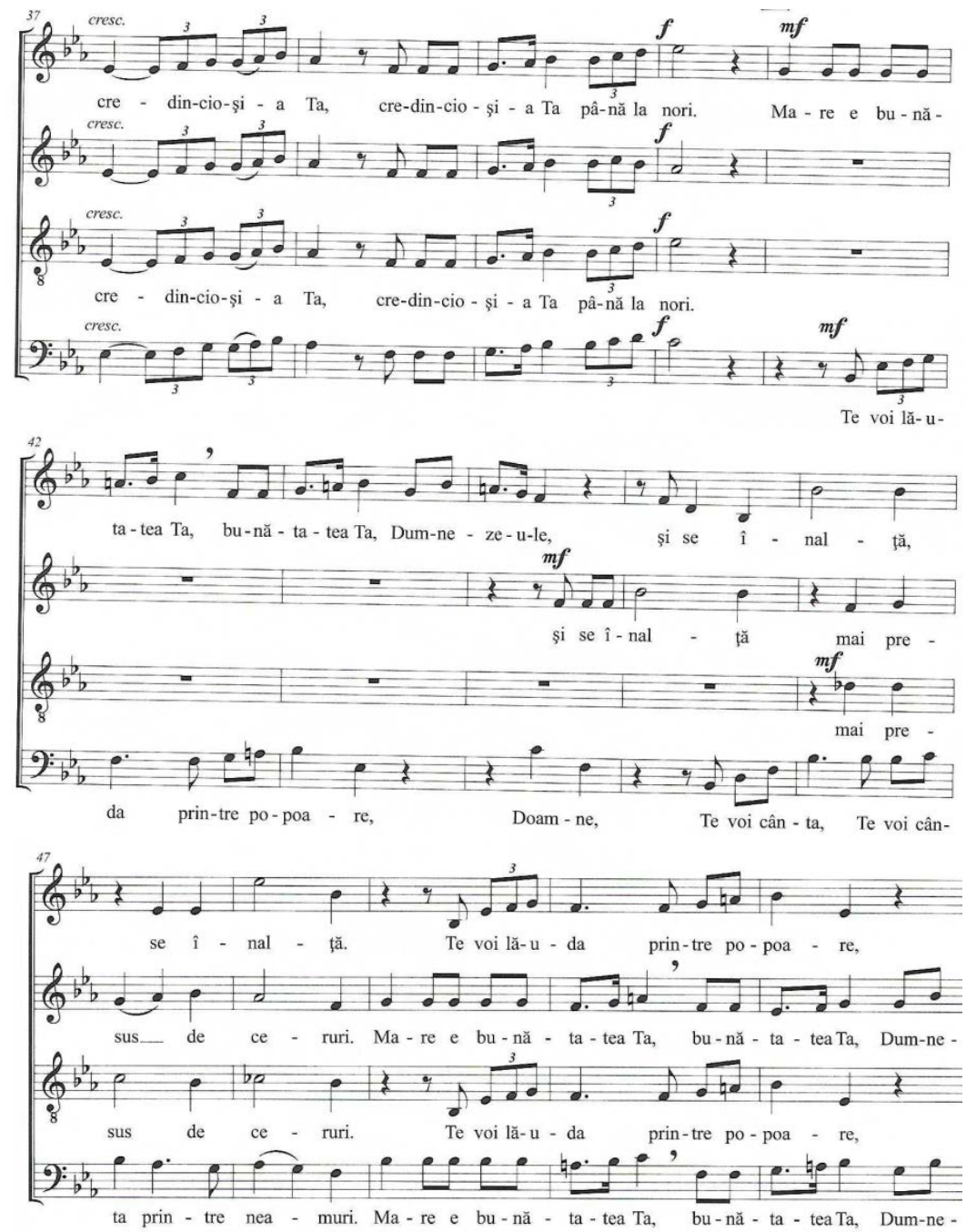

Fig. 7 Kenneth Tukker, Gata îmi este inima să cânte [Ready is my heart to sing], mm. 41-51

In verse 5, Inalţă-Te peste ceruri Dumnezeule, şi fie slava Ta peste tot pământul/ Rise above the heavens, God, and may your glory effuse all over the earth, to render the feeling of exaltation, the composer uses a rhythmicmelodic cell based on the tierce interval, which, by sequencing, gains more and more in height, the ascension being supported by the gradual increase of the intensity. 


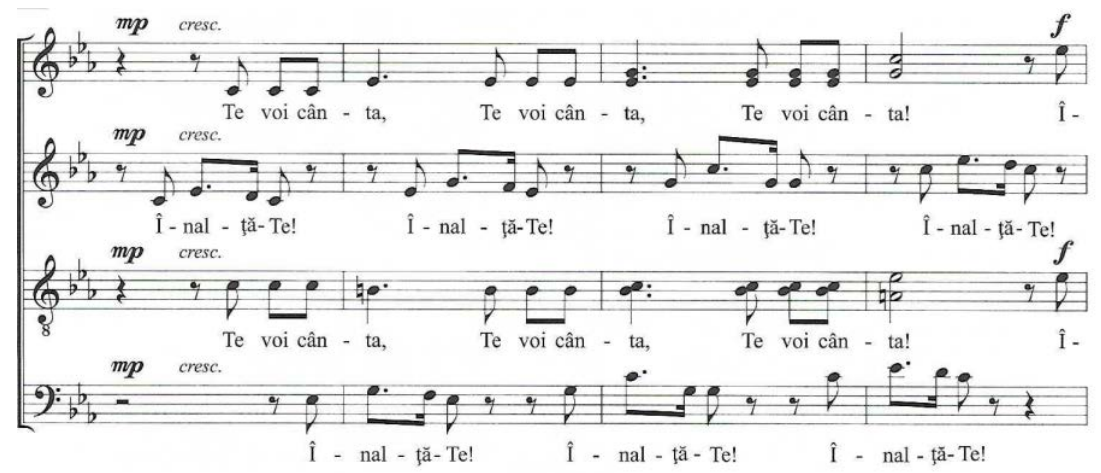

Fig. 8 Kenneth Tukker, Gata îmi este inima să cânte [Ready is my heart to sing], mm. 57-60

\subsection{Colindul păstorilor ${ }^{3}$ [Shepherds' carol] - Iulian Teodorescu}

Unparalleled from the choral repertoires dedicated to the Savior's birth, the choral work Shepherds' Carol, of the composer Iulian Teodorescu, on lyrics by Carmen Gavril, has a varied form on the multiple ostinato. The gradation made with great art, is built up by the gradual accumulation of voices from 1 to 6 , each party having an ostinated melodic phrase.

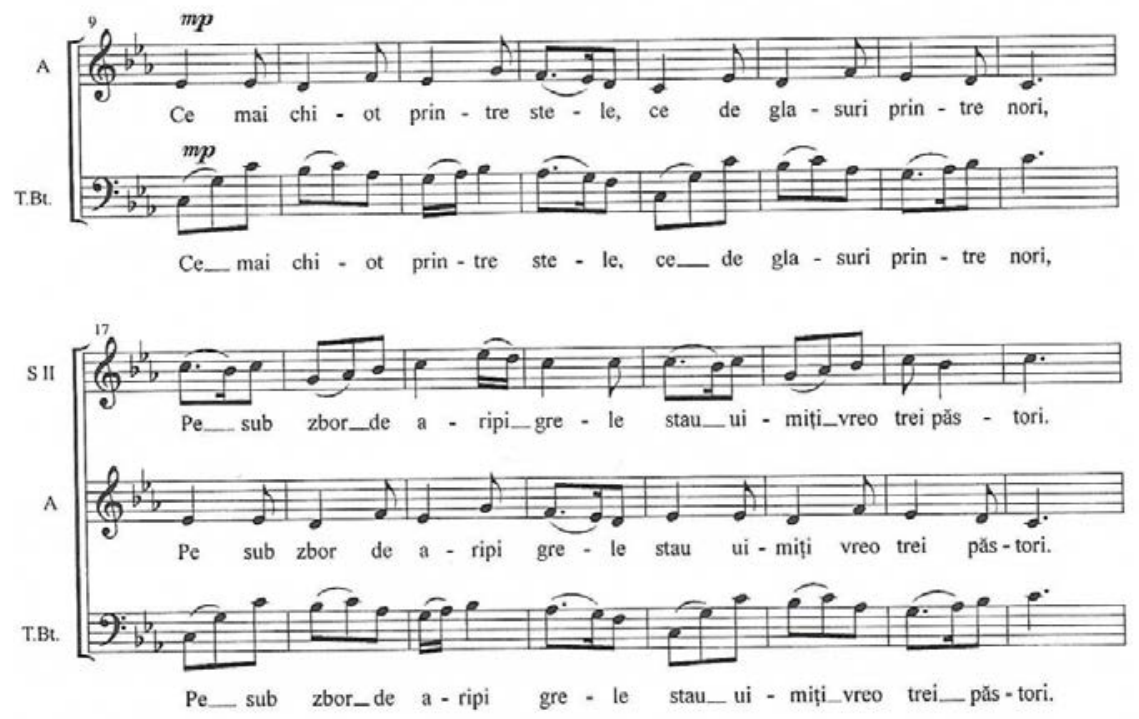

Fig. 9 Iulian Teodorescu, Colindul păstorilor [Shepherds' Carol], mm. 9-16; 17-24

The piece starts with a main song of 8 measures, followed by another five in overlap. The main song, grafted on a ternary meter (3/8), conceived in Aeolian mode

\footnotetext{
${ }^{3}$ Piece no. 4 from În mijlocul laudelor [In the middle of praise], choral religious works, special edition for the Nativity Feast, Volume II/2003. Oradea: Editura Jubilate.
} 
on do, intoned in unison by the tenor and baritone voices, on the la-la-la sylables, in the piano, persists in the listener's ear until the end.

T.Bt.

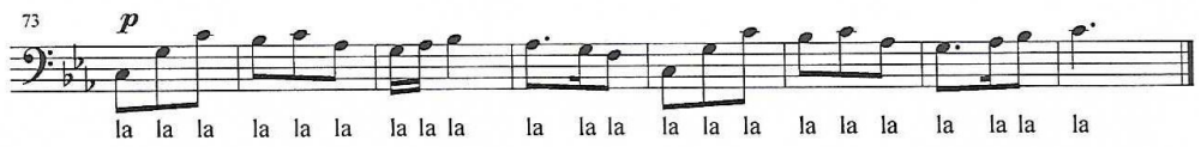

Fig. 10 Iulian Teodorescu, Colindul păstorilor [Shepherds' Carol], mm. 73-80

The descending slope of the dramatic arch is made in a concentrated time, reaching the repeat of the first idea at the tenor-baritone, the composer Iulian Teodorescu thus succeeding in capitalizing on the beauty of the poetic text and emphasizing the central idea of the message Slavă'n locurile 'nalte/ Pace fie pe pământ/ Glory in the high places/ May the earth be covered in peace.

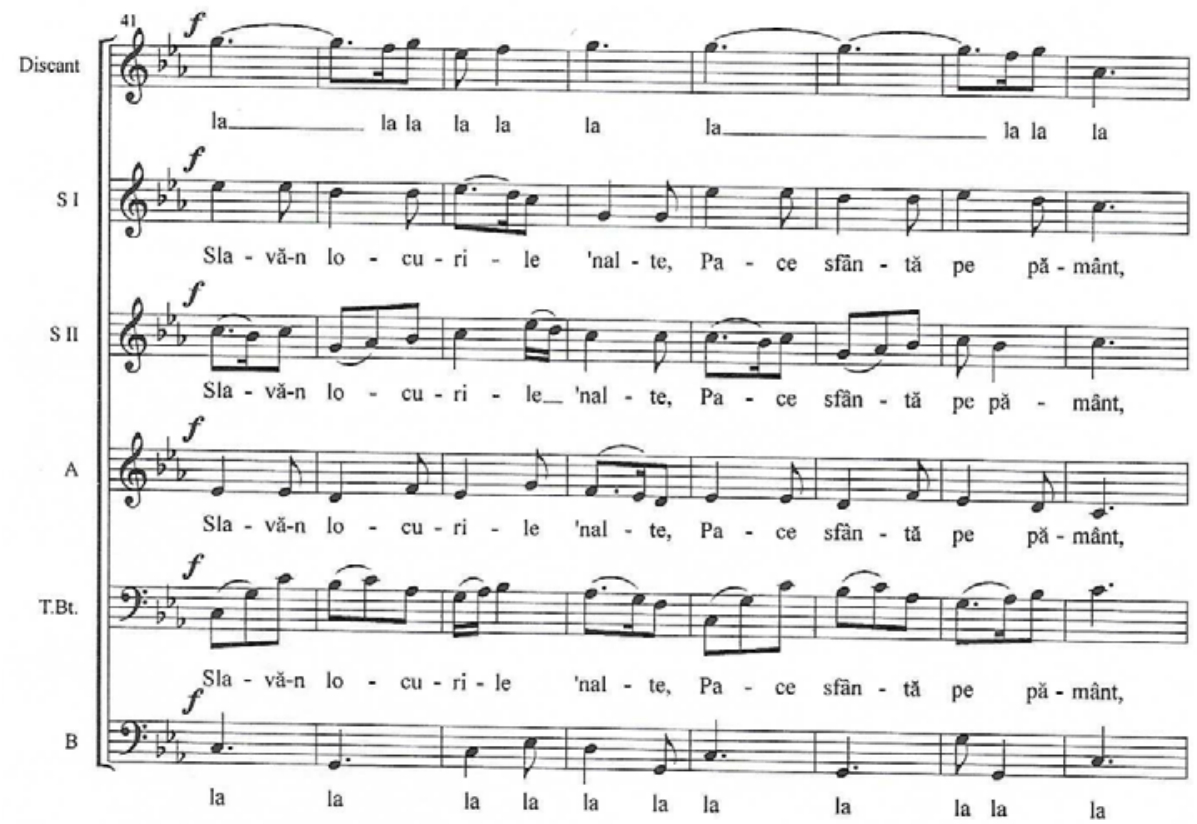

Fig. 11 Iulian Teodorescu, Colindul păstorilor [Shepherds' Carol], mm. 41-48

\subsection{Toți să fie una ${ }^{4}$ [Let all be one] - Emanuel Bălăceanu}

One of the most beautiful prayers presented in the Holy Scripture is that of the Savior's before His ascension to Heaven, as the Gospel of John, chapter 17 relates. The central point of the chapter is the unity of the believers for whom the Savior prays, by entrusting them to the Father for be guarded by the

${ }^{4}$ From the collection De laudă slavei Sale [Praise to His glory] (2015). Oradea: Editura Jubilate. 
evil one, and to be witnesses of his saving work for the next generations.

The choral work Toți să fie una/ Let all be one of the composer Emanuel Bălăceanu is inspired from verses 11, 17 and 21 of this chapter (Eu nu mai sunt în lume, dar ei sunt în lume, și Eu vin la Tine. Sfinte Tată, păzește, în Numele Tău, pe aceia pe care Mi i-ai dat, pentru ca ei să fie una, cum suntem și Noi. Sfințește-i prin adevărul Tău: Cuvântul Tău este adevărul. Mă rog ca toți să fie una, cum Tu, Tată, ești în Mine, și Eu în Tine; ca și ei să fie una în Noi, pentru ca lumea să creadă că Tu M-ai trimis/ I am no longer in the world, but they are in it, and I come to you. Holy Father, watch over those whom You have given Me, that they may be one, as We are, sanctify them by Your truth: Your word is the truth. I pray that all will be one, as You, Father, are in Me, and I in You; so that they too, may be one in Us, that the world may believe that You have sent $\mathrm{Me}$ ), and they are intoned in the evangelical churches usually on the Sunday of the Lord's Supper (an act in which the believers share bread and wine), before preaching from the Holy Scripture, according to a theme appropriate to the moment.

To render the idea of unity as stated in the Scriptural text (Mă rog ca toți să fie una/ I pray that all will be one), composer Emanuel Bălăceanu uses the unison he alternates with writing in 4 voices. The piece starts with a warm melody that drives us into the atmosphere of prayer, intoned by the tenor-bass voices, to whom the sopran-alto gradually joins.

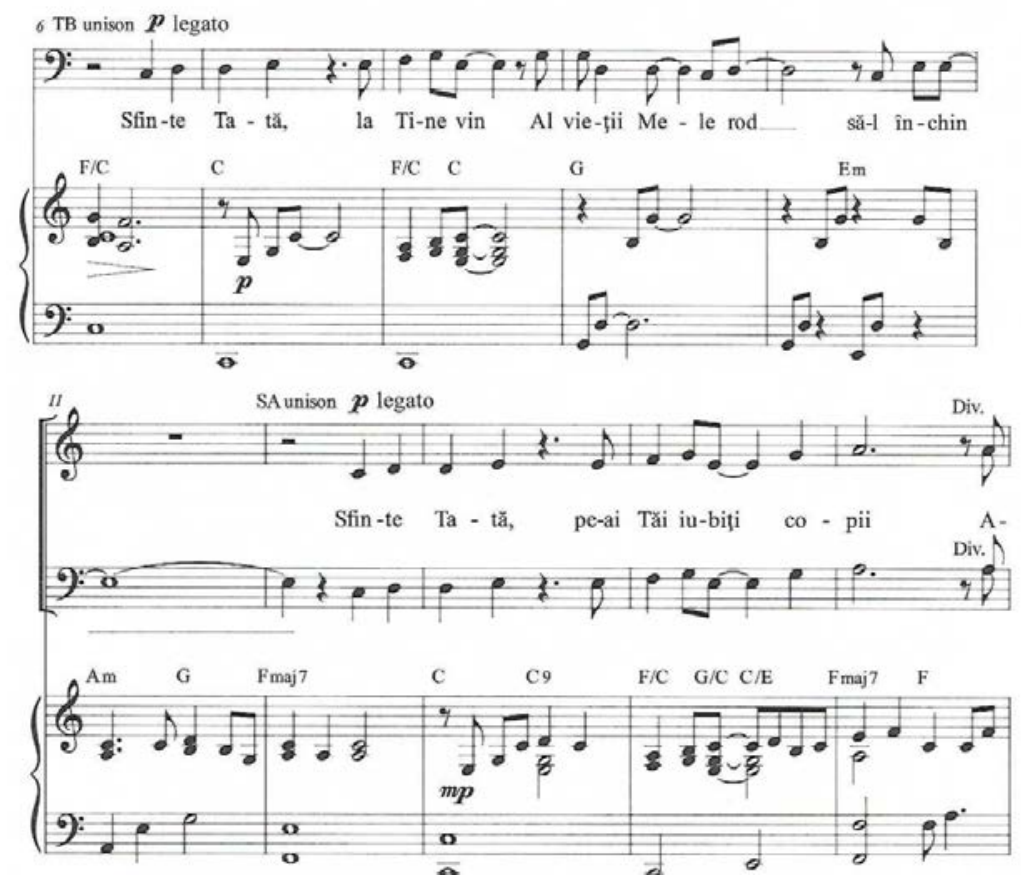

Fig. 12 Emanuel Bălăceanu, Toţi să fie una [Let all be one], mm. 6-15 
After a short passage of four voices, the first part of the chorus is rendered in unison by the whole coral ensemble, while the piano performs a discrete accompaniment, made of arpeggios.

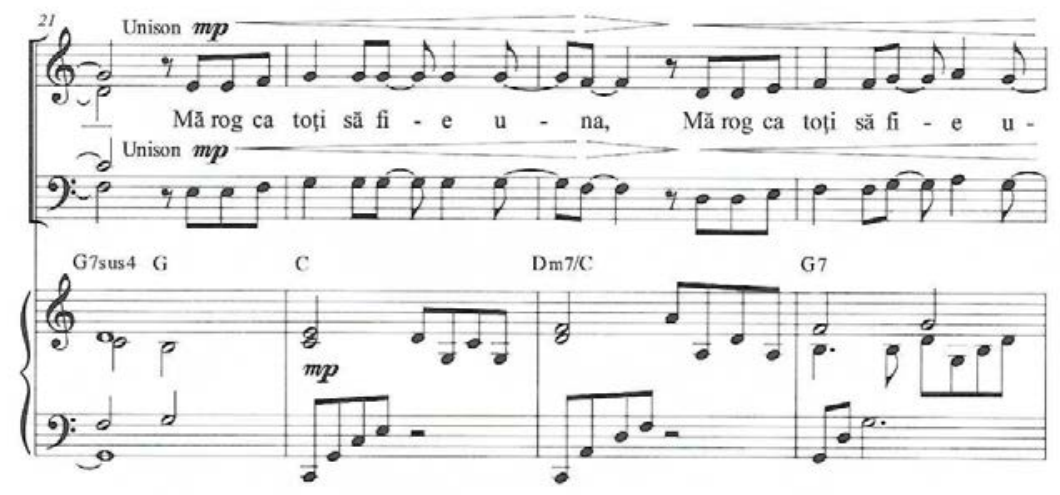

Fig. 13 Emanuel Bălăceanu, Toți să fie una [Let all be one], mm. 21-24

By repeatedly using the verse $M a ̆$ rog ca toți să fie una/ I pray that all will be one, the gradual accumulation of intensity (p, $\mathrm{mf}, \mathrm{f}$ ), the presence of a short imitation passage, the pedal to four voices, and the use of quote (over the pedal to four voices, the first verse of a well known song, that is sung with the entire community, Noi suntem una-n Isus/ We are one in Jesus is heard intoned by the sopran solo), the work follows an expressive forceful evolution.
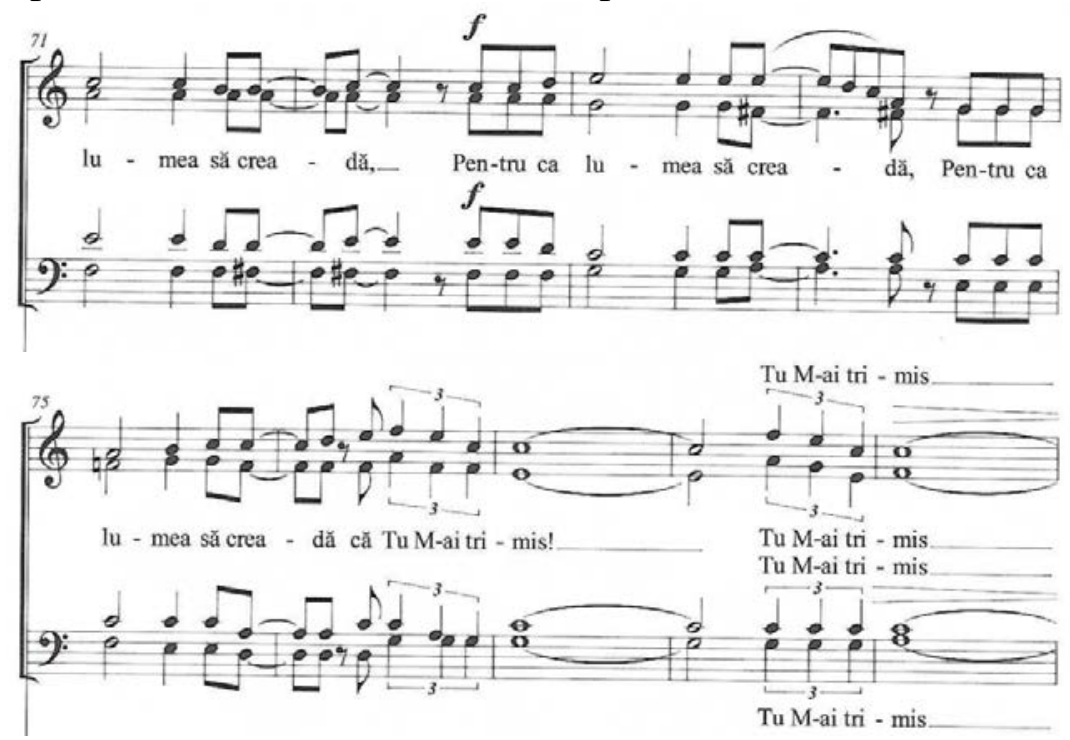

Fig. 14 Emanuel Bălăceanu, Toți să fie una [Let all be one], mm. 71-74

The entire fragment is supported by the piano with a harmony made from chords with added sounds. 


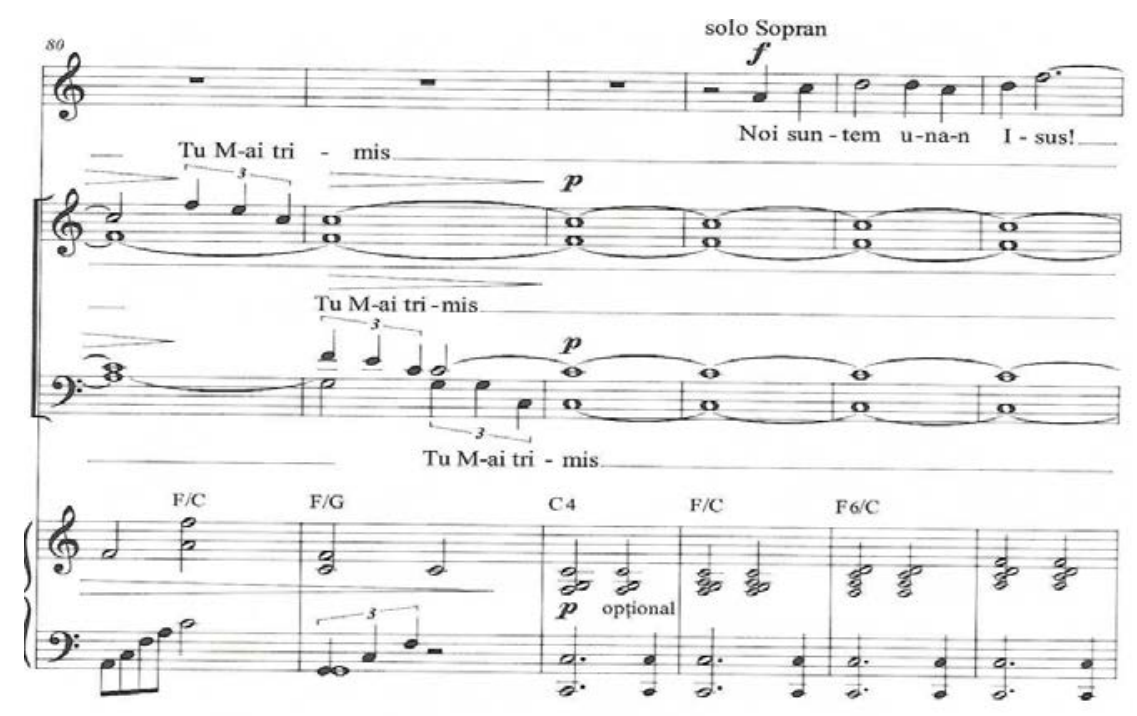

Fig. 15 Emanuel Bălăceanu, Toţi să fie una [Let all be one], mm. 80-85

The idea of unity is also found in the final refrain that modulates at an ascendent large second interval, also exposed in unison.

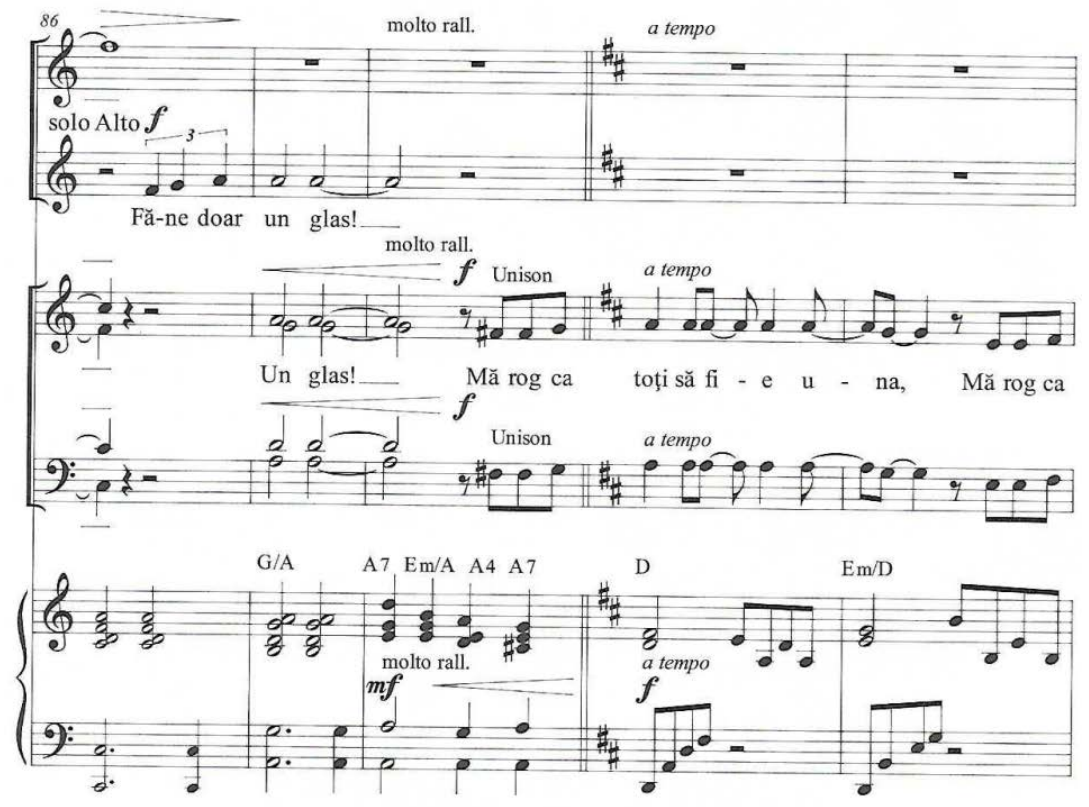

Fig. 16 Emanuel Bălăceanu, Toți să fie una [Let all be one], mm. 86-90

The piece ends with a forceful and brilliant sonority (ff), which comes to strengthen the believers' faith and optimism, expressed in the verse Pentru ca lumea să creadă că Tu M-ai trimis/For the world to believe that You have sent 
$M e$, and in order to accomplish this, the composer calls for increased support from the voice and piano apparatus.

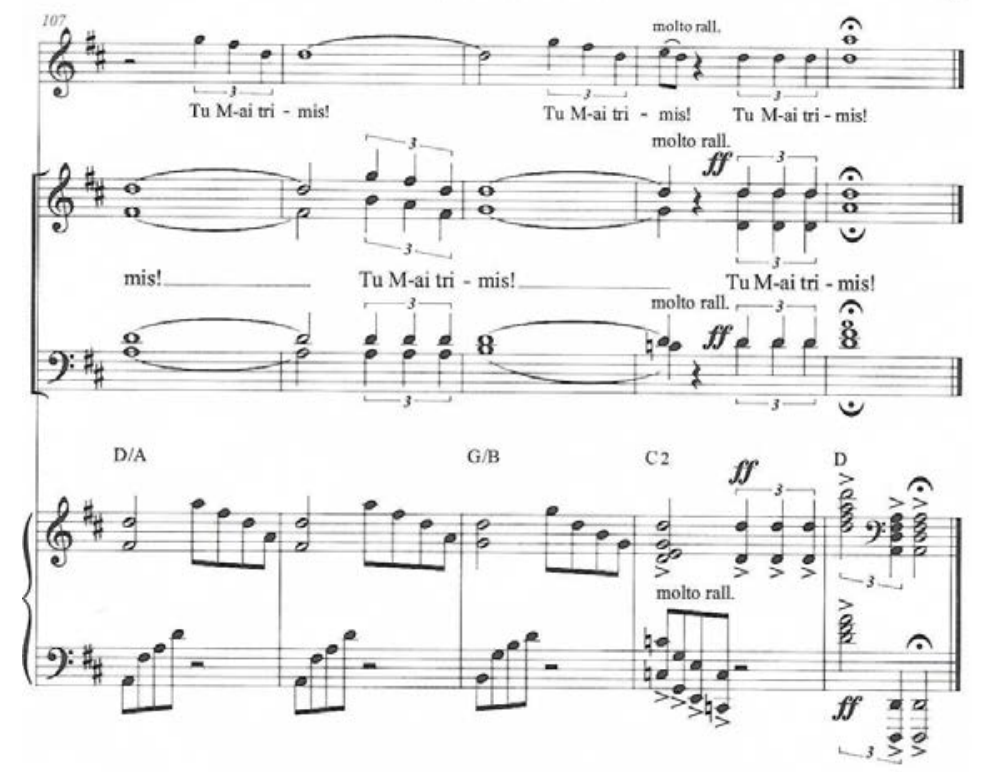

Fig. 17 Emanuel Bălăceanu, Toţi să fie una [Let all be one], mm. 107-111

\section{Conclusions}

The course of music in the life of non-protestant churches and the constant preoccupation for defining the songs repertoire has been and is in constant change. Both in liturgical serivices and in a secular framework, the ability of the art to communicate biblical truths represents the most important liturgical feature. By browsing the pages of the Holy Scripture, we discover that Christians have always been involved in art. As they headed for eternity, they contributed to the most beautiful forms of artistic expression for God.

Using a varied and meaningful language, contemporary neo-protestant choral creation evolves in the rhythm of the development of human civilization, reflecting society in its diversity, and at the same time being an effective way of communicating between past and present.

\section{References}

Bălăceanu, E. (2015). Toți să fie una [Let all be one] din colecţia De laudă slavei Sale [Praise to His glory]. Oradea: Editura Jubilate.

Buzduga, S. (2015). Închinarea și lauda în acord cu Sfânta Scriptură [Worship and praise in accordance with Holy Scripture]. Suceava: Editura Little Lamb.

Caciora, T. (2011). Concepte componistice şi interpretative moderne. O viziune asupra propriei creații şi activităti interpretative [Modern composing and interpreting 
concepts. A vision of their own creation and interpretative activities]. Iaşi: Editura Artes.

Caciora, T. (2011). Aranjamente corale [Choral arrangements]. Iaşi: Editura Artes.

Eisikovitz, M. (1976). Introducere în polifonia vocală a secolului XX-prelucrarea corală a folclorului [Introduction to vocal polyphony of the 20th century - choral processing of folklore]. Bucureşti: Editura Muzicală.

Filip, I. (2012). Elemente de limbaj muzical [Elements of musical language]. Arad: Vasile Goldiş Press.

Geantă, C. (1999). O istorie subiectivă a muzicii în Biserica Adventistă de Ziua Șaptea din România [A subjective history of music in the Seventh-day Adventist Church in Romania]. Bucureşti: Editura Viață și sănătate.

Geantă, C. (2009). Estetica muzicii sacre [Aesthetics of sacred music]. București: Editura Viaţă şi sănătate.

Gelman, K. S. (2004). Polifonia imitativă în creaţia corală contemporană românească [Imitative polyphony in contemporary Romanian choral creation]. Cluj-Napoca: Editura Napoca Star.

Jarda, T. (2003). Armonia modală cu aplicaţii la cântecul popular românesc [The modal harmony with applications in the Romanian folk song]. Cluj Napoca: Editura MediaMusica.

Talpoş, V. (1999). Studiu introductiv în Legea, Istoria şi Poezia Vechiului Testament [Introduction to the Old Testament Law, History and Poetry]. Bucureşti: Editura Didactică şi Pedagogică.

Terényi, E. (2001). Armonia muzicii moderne [Harmony of modern music]. Cluj-Napoca: Editura MediaMusica.

Timaru, V. (1991). Morfologia şi structura formei muzicale. Curs de forme şi analize muzicale [Morphology and structure of musical form. Course of musical forms and analysis], I. Cluj-Napoca: Academia de Muzică „Gheorghe Dima”.

Timaru, V. (1994). Principiul stroficităţii. Curs de forme şi analize muzicale [The Principle of stanza. Course of musical forms and analysis], volume II, Cluj-Napoca: Academia de Muzică „Gheorghe Dima”.

Velea, M. (2004). Evoluţia muzicii psaltice şi a mişcării corale religioase din România [The Evolution of psaltic music and religious choral movement from Romania]. Bucureşti: Editura Daim.

Un ospăt nesfârşit [A neverending feast], culegere de piese corale pentru cor mixt [collection of choral pieces for mixed choir] (2012). Oradea: Editura Jubilate.

În mijlocul laudelor [In the middle of praise], lucrări corale bisericeşti [religious choral works], ediţie specială pentru Sărbătoarea Naşterii Domnului [special edition for the Feast of Nativity], I (2003). Oradea: Editura Jubilate. 